\title{
Epidemic Science
}

\author{
R Saravana Kumar ${ }^{1}$, Subash Chandra Parija ${ }^{2}$ \\ Journal of Scientific Dentistry (2020): 10.5005/jp-journals-10083-0937
}

Epidemics do more than cause death and debilitation: they increase the pressure on healthcare systems and their workers. This can promote distrust between the community, governments, and health systems, although positive outcomes have been found to strengthen relations between communities and healthcare authorities.

In our response, we must consider epidemics not as discrete events but rather as connected cycles for which we can prepare, even if we cannot predict specific outbreaks. The challenge is then to choose the right response at the right scale in the right area at the right time. There needs to be a greater emphasis on absorbing and using positive lessons from each episode and avoiding those that led to negative outcomes. The challenges in this epidemic are real and changing: future epidemics will be fueled by conflict, poverty, climate change, urbanization, and the broader demographic transition.

A modern approach that is capable of characterizing epidemics and the best ways to control them must go beyond a narrow definition of epidemiology that sustains artificial barriers between disciplines. Instead, it must be able to integrate tools and practices from a diverse range of established and emerging scientific, humanistic, political, diplomatic, and security fields. We believe that such an approach needs to become the norm for the curriculums of schools of public health around the world. The way that we train practitioners and researchers working in all fields relevant to today's epidemic landscape has to change.

We need to train the next generation of epidemiologists to have the skills, knowledge, and networks to recognize and make use of
${ }^{1}$ Department of Periodontology, Indira Gandhi Institute of Dental Sciences, Sri Balaji Vidyapeeth, Puducherry, India

${ }^{2}$ Vice Chancellor, Sri Balaji Vidyapeeth, Puducherry, India

Corresponding Author: Subhash Chandra Parija, Vice Chancellor, Sri Balaji Vidyapeeth, Puducherry, India, Phone: +91 9443999511, e-mail: subhashparija@gmail.com

How to cite this article: Saravana Kumar R, Parija SC. Epidemic Science. J Sci Dent 2020;10(2):31.

Source of support: Nil

Conflict of interest: None

every tool available to help them to do their work effectively; the entire architecture of the response to epidemics has to be adapted. Only then will we be able to maintain the comprehensive and effective response-including prevention and research — needed to stop epidemics and protect people's lives, no matter what the circumstances. ${ }^{1,2}$

\section{References}

1. Huber C, Finelli L, Stevens W. The economic and social burden of the 2014 Ebola outbreak in West Africa. J Infect Dis 2018;218(Suppl 5): S698-S704. DOI: 10.1093/infdis/jiy213.

2. Ebola Gbalo Research Group. Responding to the Ebola virus disease outbreak in DR Congo: when will we learn from Sierra Leone? Lancet 2019;393(10191):2647-2650. DOI: 10.1016/S0140-6736(19)31211-5.

(c) The Author(s). 2020 Open Access This article is distributed under the terms of the Creative Commons Attribution 4.0 International License (https://creativecommons. org/licenses/by-nc/4.0/), which permits unrestricted use, distribution, and non-commercial reproduction in any medium, provided you give appropriate credit to the original author(s) and the source, provide a link to the Creative Commons license, and indicate if changes were made. The Creative Commons Public Domain Dedication waiver (http://creativecommons.org/publicdomain/zero/1.0/) applies to the data made available in this article, unless otherwise stated. 